\title{
Correction to: Water quality assessment and hydrogeochemical characterization of the Complex Terminal aquifer in Souf valley, Algeria
}

\author{
Mohammed Ouarekh $^{1} \cdot$ Boualem Bouselsal ${ }^{1}(1) \cdot$ Mohamed Salah Belksier ${ }^{1} \cdot$ Lahcen Benaabidate $^{2}$
}

Published online: 2 December 2021

(c) Saudi Society for Geosciences 2021

Correction to: Arabian Journal of Geosciences (2021) 14: 2239

https://doi.org/10.1007/s12517-021-08498-x

In this article the author name "Mohamed Salah Belksier"

was incorrectly written as "Mohamed Salah Elksier".

The original article has been corrected.

The original article can be found online at https://doi.org/10.1007/ s12517-021-08498-x

Boualem Bouselsal

bousboualem@gmail.com

1 Laboratory of underground oil, gas and aquifer reservoirs, Department of Earth and Universe Sciences, University of Kasdi Merbah, Route de Ghardaia, BP 511, 30000 Ouargla, Algeria

2 Laboratory of Functional Ecology and Environment Engineering, Faculty of Sciences \& Techniques, University of Sidi Mohammed Ben Abdellah, 30000 Fez, Morocco 